\title{
Emerging Policy issues in the Special Crop Productions Programme of Benue State
}

\author{
${ }^{*}$ Bauchi, B. M, ${ }^{* *}$ M. C. Madukwe, ${ }^{* *}$ S. Daudu, and ** E. A. Onwubuya \\ * Ministry of Agriculture, Makurdi \\ ${ }^{* *}$ Department of Agricultural Extension, University of Nigeria, Nsukka \\ ${ }^{* * *}$ Extension and Communication Department, University of Agriculture, Makurdi
}

\begin{abstract}
This study was carried out to examine the characteristics of the Special Crop Production Programme of the Benue State Ministry of Agriculture, Makurdi and highlight the emerging policy issues. Primary data were collected through structured questionnaire from 120 respondents who were randomly selected. Analysis of data was carried out using percentages and mean scores. Results showed that, procurement and distribution of inputs (improved seeds, fertilizer and herbicides) were insufficient and untimely provided. The situation forced farmers to acquire most of their input from the open market at exorbitant prices. Farmers were not involved in the planning of the programme and the extension personnel attached to the programme were not sufficient for effective delivery of extension services to farmers. The recommendations are that policy should be put in place to ensure early procurement and distribution of inputs at affordable prices, organize farmers into farmers associations and co-operatives to help pool farm lands, input procurement, and access to the use of machinery and providing market outlets for disposing farmers' outputs. This way a veritable extension policy for crop production will be ensured in Nigeria.
\end{abstract}

Key words: Characteristics, Special crop production programme, Benue State.

\section{INTRODUCTION}

In a bid to ensure food security, the Nigerian Government recently initiated activities that would improve agricultural development. These include among others, the Special Programme for Food Security (SPFS) implemented by the State ministry of Agriculture (FGN and FAO, 2000). This programme aim at extending the application of innovative technical and institutional low cost approaches to food production; improving the productivity and sustainability of agricultural system with the ultimate objective of contributing to better livelihood of the poor people.

The SPFS aims at assisting farmers in achieving their potentials for increasing output and production and consequently their incomes on sustainable basis; Crops to be grown include cereal, legumes, tubers and tree crops. Under the programme, Benue State has the mandate of producing rice, maize, soybeans and beniseed, which are suited to the agro-ecological conditions prevalent in the state. 
The Special Crop Production Programme of the Benue State MOA has been in operation since the year 2000 . The general objective of the study was to identify the characteristics of the Special Crop Production Programme of the Benue State Ministry of Agriculture (MOA). Specifically, the study was designed to:

- describe the characteristics of farmers participating in the programme.

- ascertain the characteristics of personnel attached to the programme; and

- examine the characteristics of the programme.

- Based on the above identify the emerging policy issues for improving the delivery of the programme.

\section{METHODOLOGY}

This study was carried out in Benue State of Nigeria. It has a total land area of 34059 $\mathrm{km}^{2}$ and a population of 4,219,244 people (NPC, 2006). The state is situated between longitude $7^{\circ} 30 \mathrm{E}$ and $10^{\circ} \mathrm{E}$ latitude $6^{\circ} 30 \mathrm{~N}$ and $8^{\circ} 30 \mathrm{~N}$. The state has 23 Local Government Areas with Makurdi town as the state capital. (BNARDA, 1994 and 1997)

The sample for the study was drawn from the three (3) agricultural zones of the state. For each zone, one local government was randomly selected, making up three local government areas for the study. Each town has 60 SCPP Farmers. Two (2) towns were randomly selected from each local government, making a total of six towns (6 towns). One village from each town was randomly selected giving a total of six (6) villages and from each village twelve (12) participating farmers were randomly selected giving a total of seventy-two (72) respondents. Twelve (12) extension staff from each zone were randomly selected giving a total of thirty-six (36) extension staff and twelve (12) management staff were purposively selected totaling forty-eight (48) staff, with grand total of one hundred and twenty (120) respondents. Objectives one to five were analyzed using percentage and mean score respectively.

\section{RESULTS AND DISCUSSION \\ Characteristics of Farmers Participating in the Programme Participation in Planning}

Table 1 shows that most farmers $(76.9 \%)$ participating in the programme were not involved in the planning of the programme. Those who accepted being involved $(23.1 \%)$ were however involved at the sites of demonstration plots as committee members.

These results confirm what Agbamu, (2005) earlier stated that, management of agricultural extension programmes in developing countries deny farmers involvement in planning for the programme they will implement.

When respondents were asked how they acquire land, $8.3 \%$ indicated they acquire community land, $3.7 \%$ of the respondents use personal land and the majority $(81.5 \%)$ use family land. These findings show that, most respondents use family land for cultivation. The use of family land may hinder large-scale production, since family land is distributed among male children in the family; hence large families may encounter problems of scarcity of land and may tend to migrate. 
Journal of Agricultural Extension

Vol. 12 (1) June, 2008

TABLE 1: Distribution of farmers by farming characteristics

\begin{tabular}{lc}
\hline Characteristics of farmers & $\begin{array}{c}\text { Percentage } \\
\text { (n = 108) }\end{array}$ \\
\hline Involvement in planning of programme & 23.1 \\
None involvement & 76.9 \\
Land tenure/ownership: & \\
Community land & 8.3 \\
Personal land & 3.7 \\
Leased land & 3.7 \\
Family inheritance & 81.5 \\
Government land & 2.8 \\
Type of Labour: & \\
Manual Labour (family/Hired) & 89.9 \\
Mechanized Labour & 10.1 \\
Use of tractor services: & 12.9 \\
Yes & 87.1 \\
No & \\
Type of seeds used: & 79.6 \\
Improved seeds & 20.4 \\
Local variety & \\
Reasons for not using improved seeds: & 19.9 \\
They are expensive & 31.1 \\
They are not easily available & 43.0 \\
They require more fertilizer which is expensive & 7.0 \\
I don't want to use improved seeds & \\
Application of fertilizer: & 94.4 \\
Use of fertilizer & 5.6 \\
None application of fertilizer & \\
Reasons for not applying fertilizer: & 13.0 \\
Fertilizer is not easily available & 84.2 \\
Fertilizer is very expensive & 2.8 \\
Subsidized fertilizer arrive too late & \\
Use of herbicides: & 41.5 \\
Farmers who use herbicide & 58.5 \\
Farmers not using herbicide & \\
Reasons: & 75.6 \\
Herbicide are too costly & 24.4 \\
Herbicide are not easily available & \\
Source:Figld & \\
\hline
\end{tabular}

Source: Field data, September 2005.

Table 1 also indicates that $89.9 \%$ of farmers use family labour (manual). This finding confirms what Njoku, (2000) had earlier asserted that, smallholder farmers depend largely on family labour which is now diminishing as a result of migration, thus raising the cost of hired labour. Farmers using mechanized labour were $10.1 \%$. When farmers were further asked of their capability of using tractor services, majority $(87.1 \%)$ agreed that they cannot afford using tractor services because of the high cost. $12.9 \%$ agreed of being capable of using tractor services. 
This confirms the findings of Idachaba, (1991) who affirmed that, the prices of mechanized services are out of reach for the average farmer. The situation makes it impossible for our smallholder farmers to embark on large-scale production. Since majority $(89.9 \%)$ of farmers use family labour, it further explains while large scale production was difficult.

Table 1 also reveals that most (79.6\%) respondents use improved seeds. while $20.4 \%$ used local varieties. Also majority (43.0\%) who do not use improved seeds complained that they require more fertilizer, which is expensive.

The evidence from the findings show that most farmers use improved seeds, hence there is tendency for increased output. Most of the respondents (94.4\%) apply fertilizer on their crops. This shows that, farmers are aware of the need to apply fertilizer to improved their soil.

When farmers were further asked if fertilizer was purchased at an affordable price, a majority (84.3\%) indicated that, fertilizer was purchased at a high price. This situation confirm the views of Jaachin, (1991) and Amalu, (1998) that insufficient and late arrival of fertilizer often results in: fertilizer application that are well below the recommended rates and failing to realize the maximum yield potentials of new varieties that require adequate fertilizer for maximum yield.

Table 1 also shows that $41.5 \%$ of farmers apply herbicide on their crops, but majority $(58.5 \%)$ does not apply herbicide. The finding indicates that many farmers did not use herbicide to control weed in their crops. In such situations, for crops to be intensified, FGN and FAO, (2000) opined that, it must be promoted by the introduction of high yielding and disease resistant crop varieties.

\section{Characteristics of Personnel Attached to the Programme Qualification of Extension Personnel}

Table 2 reveals the qualification of extension personnel. The result shows that, $53.4 \%$ of the respondents had sub-university educational qualification (OND/NCE). While those with HND/BS.c/MS.c accounted for $43.8 \%$ and $2.8 \%$ had secondary school qualification.

TABLE 2: Distribution of Extension Personnel by Qualification

Qualification Percentage

$(n=36)$

Secondary certificate course in agriculture

OND/NCE

$\mathrm{HND/BSC/MSC}$

43.8

Source: Field data, September 2005 
Vol. 12 (1) June, 2008

The result shows that, most extension personnel have a sub-university qualification, which is not very suitable for extension service. Chuta, (1992), Eze, (1994) and Asiabaka (2002) noted that, the sub-university degree affects the effectiveness of extension service. This finding confirm the statement of Swanson, (1997) who stated that, lots of front-line extension workers in Africa are characterized by low qualifications such as secondary school and OND/HND certificates. Agbamu (2002) suggested that frontline extension agents should possess a university degree like most of their Japanese counterpart to enable them perform with utmost confidence.

\section{Extension/farmer ratio}

Table 3 indicates that majority (33.3\%) of the 40 extension personnel attached to the programme worked with 500-1000 farmers. The mean/average extension farmer's ratio was 1:1597.2. This is high and not convenient for effective extension service delivery. This implies that only few farmers may be reached by the extension service, this is because the more the extension hands the more the coverage of the area of intervension and effectiveness of extension (Agbamu 2005).

TABLE 3: Distribution of extension/farmers worked with $\mathbf{n}=\mathbf{3 6}$

\begin{tabular}{|c|c|c|c|c|c|c|c|c|}
\hline \multicolumn{4}{|c|}{ Extension/Farmer Ratio } & $\mathbf{F}$ & $\mathbf{M}$ & FM & $\%$ & $\mathbf{x}$ \\
\hline \multicolumn{4}{|c|}{ Farmers worked with: $500-1000$} & 12 & 750 & 900 & 33.3 & \\
\hline $\begin{array}{l}\text { Farmers } \\
1500\end{array}$ & worked & with: & $1000-$ & 6 & 1250 & 7500 & 16.7 & \\
\hline $\begin{array}{l}\text { Farmers } \\
2000\end{array}$ & worked & with: & $1500-$ & 5 & 1750 & 8750 & 13.9 & \\
\hline $\begin{array}{l}\text { Farmers } \\
2500\end{array}$ & worked & with: & $2000-$ & 7 & 2250 & 15750 & 19.4 & \\
\hline \multirow{2}{*}{$\begin{array}{l}\text { Farmers } \\
3000\end{array}$} & worked & with: & $2500-$ & 6 & 2750 & 16500 & 16.7 & 1597.2 \\
\hline & & & & 36 & & 57500 & & \\
\hline
\end{tabular}

Source: Field data, September 2005

\section{Mobility}

Table 4 shows the personnel who are mobile for effective delivery of extension service. The result shows that $76.2 \%$ of personnel attached to the programme had one means of transport or the other. Mobility is essential for extension service delivery and enhances successful extension service delivery. 
TABLE 4: Distribution of Personnel by access to mobility

\begin{tabular}{lc}
\hline \multicolumn{1}{c}{ Personnel } & $\begin{array}{c}\text { Percentage } \\
\text { (n= } \mathbf{n}=\mathbf{5})\end{array}$ \\
\hline Personnel with mobility & 76.2 \\
Personnel without mobility & 23.8 \\
\hline
\end{tabular}

Source: Field data, September 2005

\section{Characteristic of the programme}

Table 5 shows that majorities $(81.7 \%)$ of the respondents were males and $18.3 \%$ were females. This implies that, more men were benefiting from the programme. Traditionally, men farm these crops, more than women. Table5 also shows that majority of the respondents $(48.3 \%)$ were within the age bracket of $41-59$ years. This was followed by $23.3 \%$ of those who fell within $51-60$ years of age. The mean age was determined to be 44.5 years. The implication of this finding is that more of the middle aged (41 - 50) and the aged people (51-60) are involved in the progrmme than the youth. Though the programme was designed to include the youth, it was seemingly dominated by the aged people because of the increasing number of retirees in the farming system.

As also indicated in Appendix 1, majority of the respondents (95.3\%) were married, $28.3 \%$ of the respondents had household size of 14 and above, with 10 as the average number of person per household. The implication of this finding is that large household size may be an advantage to farmers in term of farm labour supply. Chidebelu, (1990) stated that, the family is the most important input of unpaid labour.

Majority (48.4\%) of the respondents had tertiary education (OND, HND, NCE, BSc, MSc, B.Ed), $23.3 \%$ had secondary education, $15 \%$ had primary education and $13.3 \%$ had no formal education. This implies that, a greater percentage of $86.7 \%$ respondents in the study area are literate and more likely to be responsive to agricultural extension programmes and policies. These findings agrees with that of Anyanwu, Olowu, and Igunnu (1994) that, the literacy level of our rural farmers is on the increase, because the increasing number of those that farm in the rural locations are urban dwellers (retired civil servants, business men and politicians) who have formal education.

When respondents were asked about their major occupation, a majority, $(59.2 \%)$ said they were farmers, $40.0 \%$ civil servants. This finding shows that majority of the respondents were practicing farmers.

\section{Provision of inputs for the programme}

Funding Respondents were asked about the timeliness of fund release, and a majority $(64.6 \%)$ said that funds were not released as and at when due. The untimely release of fund will adversely affect the overall performance of agricultural programmes. CBN, (1999) had earlier cautioned that the constraints hampering agricultural production Nigeria is the untimely release of fund. 
Journal of Agricultural Extension

Vol. 12 (1) June, 2008

\section{Budgetary allocations to the programme}

Table 6 reveals the amount allocated to the Special Crop Production Programme (SCPP) in the last five years $(2001-2005)$ and the percentage released.

TABLE 6: Percentage distribution of respondents based on funds release

\begin{tabular}{cccc}
\hline Year & $\begin{array}{c}\text { Amount } \\
\text { allocated } \\
\text { (Millions) }\end{array}$ & $\begin{array}{c}\text { Amount } \\
\text { released } \\
\text { (Millions) }\end{array}$ & Percentage \\
\hline 2001 & 20.00 & 19.00 & 95.0 \\
2002 & 20.00 & 10.00 & 50.0 \\
2003 & 25.00 & 18.00 & 72.0 \\
2004 & 25.00 & 22.85 & 91.4 \\
2005 & 200.00 & 197.45 & 98.7 \\
\hline
\end{tabular}

Source: BNS MANR data, 2005

Table 6 shows that, the highest amount allocated to the programme was in the year 2005 when the programme was restructured.

\section{Timely/sufficient inputs provided for the implementation of the programme}

Table 7 shows that, majority of the respondents $(58.3 \%)$ indicated that inputs were not sufficiently provided. Majority of the respondents $(71.1 \%)$ also agreed that, the inputs were untimely provided. This shows that, the inputs were not sufficiently procured for sale to the farmers and also not available at the right time needed for effective execution of the programme. Asiegbu, (1990) and Agwu, (1996) earlier opined that, factors influencing the adoption of new technology are the availability, accessibility, and affordability of agricultural inputs. According to them, new technologies require reasonable relevant inputs such as improved seeds, fertilizers, agro-chemicals, credit and technical equipment to enhance successful implementation. The finding shows that farmers have difficulties with timely and sufficient provision of inputs in the implementation of the programme. Table 7 also shows that, $83.3 \%$ of the farmers agreed that tractor services were made available to farmers. This they indicated enabled the increase hectrage under cultivation.

When respondents were asked if loans were made available to them, majority $(66.7 \%)$ reported that loans were not made available to them. This is because the loans available in the SCPP programme was the input loans as opposed to the traditional cash loan like farmers where used to. This raises the need to help the poor to assess affordable credit services (International Food Policy research Institute, IFPRI, 2008). This implies that implementation of the programme have hitches or problems. MOF (2002) opined that, financial resources in form of loans to farmers are very necessary for any programme to be successful, since farmers need to put in more financial resources to acquire the desired result in any new programme introduced. 
TABLE 7: Distribution of inputs for the programme as perceived by farmers

\begin{tabular}{lc}
\multicolumn{1}{c}{ Inputs available } & Percentage \\
\hline Enough inputs provided & 41.7 \\
Timely availability of inputs & 22.9 \\
Tractor services available to farmers & 83.3 \\
Availability of loans to farmers & \\
Extension services available for the \\
programme
\end{tabular}

Source: Field data, September 2005. Multiple responses recorded.

Also indicated in Table 7 is the poor availability of extension services (16.7\%) for the programme. This implies that the extension service available for the programme is not sufficient for effective implementation of the programme and this is one of the major constraints. Sammy, (1998) in his investigation of the transfer of corn technologies in Egypt found that one of the constraints to the adoption of corn technologies was lack of knowledge by farmers. Fai-Cassino, (2004) also affirmed that, with insufficient extension agents, farmers in remote areas will have no idea that government provides them with technical assistance, thereby relying on the traditional methods of agriculture inherited from their ancestors.

\section{CONCLUSION}

Based on the major finding, the following conclusions were drawn. Majority $(76.9 \%)$ of the programme participants $(84.5 \%)$ were not involved in the planning of the programme Majority of farmers acquired one to two hectares of farm land through family inheritance, and $89.9 \%$ mostly used manual labour with only $10.1 \%$ using mechanized labour. Most (79.6\%) farmers use improved seeds and $94.4 \%$ apply fertilizer on their crops no matter how inadequately applied. However, most of the fertilizers $(48.2 \%)$ were purchased mostly from the open market.

The Majority of farmers were male and within the age bracket of $41-50$, which means they were in their productive age. Most farmers had large family size which was an added advantage for employing manual labour.

Release of funds for programme implementation was inadequate and untimely provided. Similarly loans were not provided to enhance effective implementation of the programme, At the same time, other farm inputs were inadequately and untimely provided such that, farmers were forced to acquire them in the open market at high prices. 


\section{RECOMMENDATIONS}

Based on the findings and conclusions, the following recommendations are made:

- Policy should be put in place to ensure early procurement and distribution of inputs at affordable prices.

- Stakeholders should intensity the mobilization and organization of farmers into farmers into farmers association and cooperatives to help pull farm lands, input procurement, and access to the use of machinery and providing market outlets fro disposing farmers' outputs. This way a veritable extension policy for crop production will be ensured in Nigeria.

- More extension personnel should be employed to reduce the high ratio of extension/farmer contact. The agency should make a deliberate policy for training it manpower to graduate and postgraduate level to put them in a better position to interpret research findings to farmers.

\section{References}

Agbamu J. (2002) Agricultural Research-Extension-Farmer linkage in Japan: policy issues for sustainable Agricultural Development in Developing Countries. International Journal of Society and Policy Issues. Ekpene Nigeria. Development universal consortia: 252 - 261.

Agbamu, J. (2005). Problems and Prospects of Agricultural Extension Service in Developing Countries In: Adedoyin, F.S (ed) Agricultural Extension in Nigeria. 159-164.

Agwu, A. E. (1996). Constraints in Implementing the National Agricultural Land Development Authority Programme in Abia and Enugu States of Nigeria. MSc project work. Department of Agricultural Extension, University of Nigeria Nsukka.

Amalu, C. U. (1998). Agricultural Research and Extension Delivery System in SubSaharan Africa. University of Calabar Press. pp 63-65.

Asiegbu, J. E. (1990). Crops Resources and Management in National Development, In: Ikeme, A.I(Ed). The challenge of Agriculture in National Development. faulty of Agriculture, UNN.Enugu optimal pulishers, pp 198-230.

Anyanwu, A.C., Olowu, T.A and Igunnu, J.B. (1994) Audience survey for radio listening groups in plateau, Imo and Osun State. A Research Report. Prepared for project NIR/87/04,FAD, Rome.

Asiabaka, CC (2002) Agricultural Extension. A hand book for development practitioners. Omoku, Rivers State molyten united services.

Bello, A. (2001) Agriscope. Newsletter of the project coordinating unit. Federal Ministry of Agriculture and Rural Development (FMARD).

BNARDA, Benue State Agricultural and Rural Development Authority (1994) The Impact of Benue State Agricultural and Rural Development Authority on Agriculture and Rural Development in Benue State Makurdi, pp 1-3.

BNARDA, Benue State Agricultural and Rural Development Authority (1997) Diagnostic Survey of Root andTubers Crop Production, Processing, Storage, Utilization and Marketing. Makurdi, Benue State pp 4-6. 
Caskey, R.J., Abaiduo, K.K., Dashield, F. and Sangiga, N. (1997) Effects of Soyabeans on Subsequent Maize Grain Yield in the Guinea Savannah Zone of West African Crop Science. J.S. (1): 31-38.

Central Bank of Nigeria (CBN) (1999) Annual Report and Statement of Account pp5558.

Chuta, R. (1992) Comparative Assessment of the Training Needs of Senior Agricultural Extension Administrators in Borno and Imo States of Nigeria. Ph.D Thesis. Department of Agricultural Extension University of Nigeria Nsukka 212.

Eze, S.O. (1994) Constraints in Implementing Extension Services in Enugu State ADP. MSc project work, Department of Agricultural Extension, UNN Nsukka, In: Ozor, 2002 Extension Professionals Perception of Privatization and Commercialization, University of Nigeria, Nsukka, pp20-21.

Federal Government of Nigeria (FGN)/ Food and Agricultural Organization (FAO) (2000) Implementation document, special programme for food security. Abuja, Nigeria.

Fai-Cassion, (2004) Shortage of agricultural staff in the division. In: The Farmers voice: A Monthly Publication on Newspaper News and Discussion on the Rural World. Published in English, Arabic and French. Publisher, Benard Njonga; pp19 vol. 1-Fadayami,T.O. (1998) Rural Development and Migration in Nigeria. (the impact of the eastern zone of Bauchi State Agricultural Development Project NISER, Ibadan Nigeria, pp 1-35.

Federation of Benue Farmers Association (FOBA) (1993), Report of the Technical Committee for an Apex Farmers Association for Benue State, Makurdi, pp 3-5.

Idachaba, F. S. (1991). The Nature of the Nigerian Food Problem. Journal of Agriculture, Science and Technology. Vol. 1 No. 1(1-77) June.

IFPRI, International Food Policy Research Institute (2008) Impact of a pro-poor community driven development project in Nigeria. IFPRI discussion paper 00756 March 2008. www.ifpri.org.

Jaachiin, V. B. (1991) Global Food Security. The Need to Stimulate Food Demand and Increase Food Production CTA Annual Report Special paper. IFPRI, Washington D USA pp XI.

MOF Ministry of Finance (2002) Benue State Budget

NPOC, National Population Commission (2006),Provisional Result 2006 National Population census Abuja Nigeria.

Njoku, P.C (2000) Nigeria Agriculture and the challenge of the $21^{\text {st }}$ century.Agroscience journal of Tropical Food, Environment and Extension. Vol:1 :No.1 pp 128.

Spedding, C.R. (1992) Freams Principles of Food and Agriculture. Blackwell Scientific Publications Cambridge, USA.

Sammy, M.M. (1998) Constraints to Effective Transfer of Corn Technologies Identified by Farmers in Menufia, Egypt, Alexandria, Journal of Agricultural Research vol. 43, No1, Pp 1-10.

Swanson, B.E (1997) Strengthening Research Extension Farmer Linkages. In: Swanson, B.E., Bentz, R.P Sofranko, A.J (eds) Improving Agricultural Extension A Reference Manual. Rome, FAO, Pp 171-178. 
Journal of Agricultural Extension

Vol. 12 (1) June, 2008

\section{Appendices}

Appendix 1: Percentage distribution of respondents by personal characteristic $(n=120)$

\section{Characteristic} Frequency

Percentage

$\mathbf{X}$

Sex:

Male

98

81.7

Female

22

18.3

Age:

$21-30$

8

5

$31-40$

24

20

$41-50$

58

48.3

$51-60$

28

23.3

$61-70$

4

3.3

44.5

Marital Status:

Married

115

95.8

Single

5

Size of Household

$1-3$

$4-6$

$7-9$

$10-12$

23

19.2

14 and above

34

28.3

10.0

Level of Education:

$\mathrm{N}$ o formal education $\quad 16$

13.3

Primary education

Secondary education

Tertiary education

\section{Religion}

Christianity

98.4

Islam

Traditional

1

Major Occupation

Farming

Trading

1

0.8

Civil servant

47

40.0

Artisan (skilled work men)

0.8 